\title{
Teaching Video NeuroImages: The signs of dystonic tremor
}

\section{Tremulous "escanciador"}

Jennifer Sharma, MD, * Daniel Macias-Garcia, MD, * Amir Zaidi, MD, and Alberto J. Espay, MD, MSc Neurology ${ }^{\circledR}$ 2018;91:e1204-e1205. doi:10.1212/WNL.0000000000006215
Correspondence

Dr. Espay

alberto.espay@uc.edu

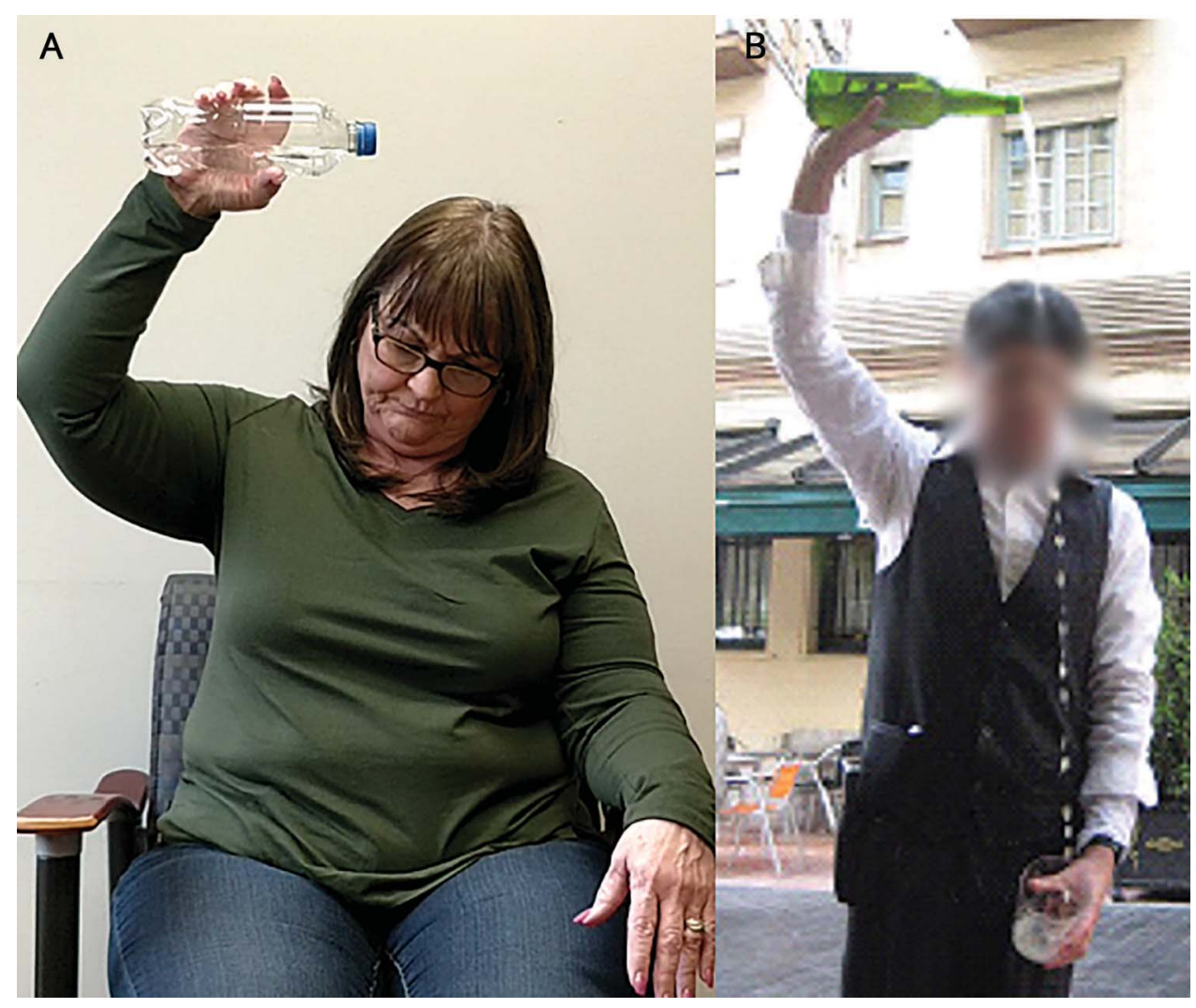

Patient holds a bottle at the position that elicited her tremor ( $\mathrm{A}$; water bottle used as "hair curler"), reminiscent of the posture adopted by an escanciador, a Spanish cider cupbearer (B).
A 58-year-old woman noticed right-hand jerky tremor exclusively while curling her hair. Her tremor-generating posture was reminiscent of the Asturian pourer of cider, or "escanciador," who holds the bottle above the head when vertically pouring to aerate the liquid (figure). On examination, we asked her to hold a water bottle as if it were a hair curler. This elicited an actioninduced, position-dependent, task-specific, weight-sensitive tremor, which attenuated when touching her affected hand with the unaffected one (closed-loop sensory feedback or sensory trick) (video 1). The rest of the examination was normal. These 5 clinical features distinguish dystonic tremor from all other tremor syndromes. ${ }^{1,2}$

\section{MORE ONLINE}

- Video

\section{$\rightarrow$ Teaching slides}

links.lww.com/WNL/ A676 


\section{Author contributions}

Drs. Sharma and Macias-Garcia drafted the manuscript and videotape. Dr. Zaidi contributed to data acquisition and review of the manuscript. Dr. Espay examined the patient and provided critical review of the manuscript.

\section{Study funding}

No targeted funding reported.

\section{Disclosure}

J. Sharma, D. Macias-Garcia, and A. Zaidi report no disclosures relevant to the manuscript. A. Espay has received grant support from the NIH, Great Lakes Neurotechnologies, and the Michael J. Fox Foundation; personal compensation as a consultant/scientific advisory board member for AbbVie, TEVA, Impax, Acadia, Acorda, Cynapsus/Sunovion, Lundbeck, and USWorldMeds; publishing royalties from Lippincott Williams \& Wilkins, Cambridge University Press, and Springer; and honoraria from AbbVie, UCB, USWorldMeds, Lundbeck, Acadia, the American Academy of Neurology, and the Movement Disorders Society. Go to Neurology.org/ $\mathrm{N}$ for full disclosures.

\section{References}

1. Albanese A, Bhatia K, Bressman SB, et al. Phenomenology and classification of dystonia: a consensus update. Mov Disord 2013;28:863-873.

2. Bhatia KP, Bain P, Bajaj N, et al; Tremor Task Force of the International Parkinson and Movement Disorder Society. Consensus Statement on the classification of tremors: from the task force on tremor of the International Parkinson and Movement Disorder Society. Mov Disord 2018;33:75-87. 


\section{Neurology}

Teaching Video NeuroImages: The signs of dystonic tremor: Tremulous "escanciador" Jennifer Sharma, Daniel Macias-Garcia, Amir Zaidi, et al.

Neurology 2018;91;e1204-e1205

DOI 10.1212/WNL.0000000000006215

This information is current as of September 17, 2018

\section{Updated Information \&} Services

References

Subspecialty Collections

Permissions \& Licensing

Reprints including high resolution figures, can be found at: http://n.neurology.org/content/91/12/e1204.full

This article cites 2 articles, 0 of which you can access for free at: http://n.neurology.org/content/91/12/e1204.full\#ref-list-1

This article, along with others on similar topics, appears in the following collection(s):

Clinical neurology examination

http://n.neurology.org/cgi/collection/clinical_neurology_examination Dystonia

http://n.neurology.org/cgi/collection/dystonia

Tremor

http://n.neurology.org/cgi/collection/tremor

Information about reproducing this article in parts (figures,tables) or in its entirety can be found online at:

http://www.neurology.org/about/about_the_journal\#permissions

Information about ordering reprints can be found online:

http://n.neurology.org/subscribers/advertise

Neurology ${ }^{\circledR}$ is the official journal of the American Academy of Neurology. Published continuously since 1951, it is now a weekly with 48 issues per year. Copyright () 2018 American Academy of Neurology. All rights reserved. Print ISSN: 0028-3878. Online ISSN: 1526-632X.

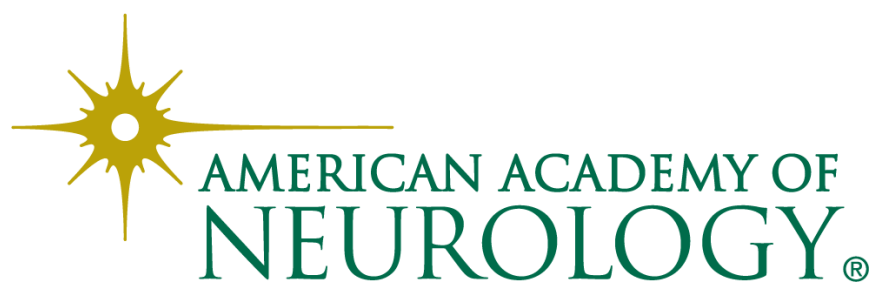

